\title{
FEEDING FODDER BEET ROOTS SUPLEMENTED WITH UREA FOR LACTATING BUFFALO
}

\author{
A.M. Mansour ${ }^{1}$ and Hoda Al-Zahar ${ }^{2}$ \\ ${ }^{1}$ Animal Production Department, Faculty of Agriculture, Ain Shams University, Cairo, Egypt. \\ ${ }^{2}$ Dairy Science Department, National Research Centre, Dokki, Giza, Egypt.
}

(Received 1/8/2017, accepted 7/9/2017)

\section{SUMMARY}

$\mathrm{T}$ welve lactating buffaloes with an average weight of $496.7 \mathrm{~kg}$ were divided randomly into three similar groups (four animals each). Each group was assigned randomly to one of the following three dietary treatments: Control ration (C) $\{60 \%$ concentrate feed mixture CFM+40\% rice straw, fodder beet ration (FB) $\{40 \% \mathrm{CFM}+20 \% \mathrm{FB}$ plus $50 \mathrm{gm}$ urea $+40 \%$ rice straw $\}$ and fodder beet silage ration, (FBS) $\{40 \% \mathrm{CFM}+20 \%$ FBS plus $50 \mathrm{gm}$ urea $+40 \%$ rice straw on DM basis. The experiment was extended for 90 days. The results showed that animals received FB ration recorded the highest values of DM, OM, CP, EE and NFE digestibility followed by FBS ration. The FB group had significant $(\mathrm{P}<0.05)$ increases in OMD and CPD, while FBS treated group had the highest values in CFD $(\mathrm{P}<0.05)$. Blood serum parameters of FB group had highest values of serum TP, albumin, A / G ratio, glucose and urea $(\mathrm{P}<0.05)$, the FBS group had the higher values of serum TP, Albumin, A /G ratio, glucose and urea $(\mathrm{P}<0.05)$ than those of control. The $(\mathrm{FB})$ group recorded the highest values of daily milk yield in all periods with average $6.99 \mathrm{~kg} /$ head $/ \mathrm{d}$., followed by FBS animals $(6.69 \mathrm{~kg} / \mathrm{h} / \mathrm{d})$ then control group $(6.51 \mathrm{~kg} / \mathrm{h} / \mathrm{d})$. The same trend was noticed with significant $(\mathrm{P}<0.05)$ increase in fat corrected milk (FCM) yield $(10.02,9.65$ and $8.90 \mathrm{~kg} / \mathrm{h} / \mathrm{d}$.) for FB, FBS and control groups, resp., FB group recorded the highest values ( $\mathrm{P}<0.05$ ) of milk total solids, SNF, TP and lactose content, while FBS treated animals had significant higher total solids content and non significant higher milk SNF, TP and ash content than the control group. The FB group had the lowest feed cost to produce one $\mathrm{kg}$ FCM (2.88 L.E.) followed by FBS treatment which recorded (2.9 L.E.), while the control group had the highest value ( 3.51 L.E.). Fodder beet group had the highest economical efficiency value (2.43) followed by FBS treatment (2.41) then the control group which had the lowest value (1.99).

Keywords: Fodder beet, silage, digestibility, blood parameters, performance, lactating buffaloes.

\section{INTRODUCTION}

In Egypt, there is a great shortage in ruminant feeds particularly in the summer and early autumn. Meantime, the common concentrate production is not quite enough and become very expensive. In recent years, the price of energy sources had dramatically increased with the increase demand for animals feeding. The increases of feed prices encouraged nutritionists to search for cheaper high energy feed ingredients Moustafa et al., 2008). So, feeding fresh fodder beet roots (FB) or ensilage FBS, as a method of conservation, may contribute in solving some of these problems. Fodder beet roots could be recommended as one of the highest producing forage in loamy and reclamation areas and it was found to be a good source of energy for animal feeding (Rammah et al., 1984). In general and new reclaimed desert lands in particular, have a large potential in expanding animal production through forage cultivation. Fodder beet plant is not sensitive and can tolerate the unfavorable conditions of reclaimed soils such as saline, alkaline calcareous and sandy lands in addition to high water irrigation salinity (Abou-Deya, 1991). 
One of the advantages of use FB as forage crop that it is a high yielding crop in terms of DM, TDN, DP and the root has a high ME content. Also, it can be considered as a low-input crop utilizing farm resources in comparison with other forage crops. Moreover, it is well known that silage are normally cheaper per unit of SV than concentrates, consequently, feeding fresh fodder beet roots or ensilage reduce the costs of animal protein and allow the country to save part of the land to raise more wheat in winter and more corn or rice in summer (Abd El-Sattar and Nour, 1997).

The objective of this study was to investigate the effects of replacing a significant proportion of concentrate feed mixture with either fresh or silage of fodder beet on lactating buffalo's performance, nutrients digestibility, some blood biochemical parameters, feed conversion and economical efficiency.

\section{MATERIALS AND METHODS}

Experimental animals: Total of twelve lactating buffaloes in their second, third and fourth lactation season with an average weight of $496.7 \mathrm{~kg}$ were allocated at random to three experimental rations (four animals each). The experiment was extended for 90 days from the beginning of lactation.

Experimental rations: Control ration (C) was introduced to the animals as $60 \%$ concentrate feed mixture (CFM) and $40 \%$ rice straw (RS) as DM basis. The second ration (FB) was introduced to the animals as $40 \%$ rice straw (RS) and one third $(33.3 \%)$ of the concentrates portion was replaced on dry matter basis by fresh fodder beet roots (FB treatment) or fodder beet roots silage (the third ration or FBS treatment). Table [1] illustrates percentage of the different ingredients in the three rations in DM basis.

Table (1). Percentages of the ingredients of the experimental ration (\% on DM basis).

\begin{tabular}{lccc}
\hline Item & $(\mathrm{C})$ & $(\mathrm{FB})$ & $(\mathrm{FBS})$ \\
\hline Concentrate feed mixture \% & 60.00 & 40.00 & 40.00 \\
Rice straw \% & 40.00 & 40.00 & 40.00 \\
Fodder beet (FB) \% & 0.00 & 20.00 & 0.00 \\
Fodder beet silage (FBS)\% & 0.00 & 0.00 & 20.00 \\
Urea ( gm/h/d) & 0.00 & 50 & 50 \\
\hline
\end{tabular}

$(C)$ Control ration , (FB) Tested ration1 and (FBS) Tested ration 2.

Fodder beet roots silage: Silage was prepared after harvesting by removing beet tops. The roots were wilted for one week then during ensiling fodder beet roots were chopped using fodder beet chopping machine, mixed with rice straw by the rate of $150 \mathrm{~kg} / \mathrm{ton}$ fodder beet roots and ensiled as described by Mahmoud et al. (1992). After two months the silo was opened, color and odor were examined and samples were taken for chemical analysis before feeding.

The daily offered portion of both concentrate and roughage were assessed to cover the maintenance requirement as well as the production requirements according to Shehata (1971). Animals were fed individually, concentrates were offered twice daily during milking times at $7.0 \mathrm{am}$. and $4.0 \mathrm{pm}$. Rice straw and fresh fodder beet or fodder beet silage were offered twice daily at $10 \mathrm{am}$. and $5 \mathrm{pm}$. Fresh water was always available to the animals. Feed requirements were adjusted for each animal biweekly. Chemical composition of the rations are presented in Table (2).

Digestibility trials: Three animals from each experimental treatment were used in a digestibility trial. A grap sample method (Forbes and Garrigus, 1948) was used and acid insoluble ash was applied for determining nutrients digestibility as a natural or internal marker (Van Keulen and Young, 1977). Feces grap samples were collected handily at 10.0 am. for five successive days from each animal after one month of the beginning of the experiment. The dried feces samples from each animal were mixed and saved for chemical analysis.

Blood samples: Blood samples were taken from three animals from each treated group at the same day of milk sampling at four hours after morning feeding from the jugular vein and left $3 \mathrm{~h}$ at room temperature to coagulate, then centrifuged at 3000 r.p.m. for 10 minutes, then blood serum was separated and stored at $-18{ }^{0} \mathrm{C}$ for chemical analysis. 
Sampling of milk: Animals were hand milked twice daily at 7.0 am. and $4.0 \mathrm{pm}$. Milk yield was recorded daily for each animal during the 12 weeks of experimental period. Samples of milk were collected once every two weeks. The sample of each animal represents a mixed sample of a constant percentage of the morning and the next evening yield. Fat content was determined, and then the samples were stored at - 18 ${ }^{0} \mathrm{C}$ for chemical analysis of the other components.

Table (2). Chemical composition of the treated rations and their ingredients.

\begin{tabular}{|c|c|c|c|c|c|c|c|c|c|}
\hline \multirow[t]{2}{*}{ Item } & \multicolumn{7}{|c|}{ Nutritional nutrients $\%$} & \multirow[b]{2}{*}{ TDN } & \multirow[b]{2}{*}{ DP } \\
\hline & $\mathrm{DM}$ & $\mathrm{OM}$ & $\mathrm{CP}$ & $\mathrm{CF}$ & $\mathrm{EE}$ & NFE & Ash & & \\
\hline $\begin{array}{l}\text { Concentrate feed } \\
\text { mixture } *\end{array}$ & 89.9 & 86.87 & 14.29 & 14.24 & 2.77 & 55.57 & 13.13 & & \\
\hline Rice straw & 87.98 & 84.33 & 3.31 & 37.16 & 1.19 & 42.67 & 15.67 & & \\
\hline $\begin{array}{l}\text { Fresh Fodder beet } \\
\text { roots (FB) }\end{array}$ & 13.46 & 89.53 & 9.78 & 9.15 & 1.87 & 68.73 & 10.47 & & \\
\hline $\begin{array}{l}\text { Fodder beet silage } \\
\text { (FBS) }\end{array}$ & 23.2 & 88.76 & 8.74 & 16.45 & 1.49 & 62.08 & 11.24 & & \\
\hline Control ration $(\mathrm{C})$ & & 86.28 & 9.90 & 23.4 & 2.14 & 50.84 & 13.82 & 62.16 & 6.81 \\
\hline ration $1(\mathrm{FB})$ Tested & & 87.80 & 9.98 & 22.38 & 1.97 & 53.47 & 12.20 & 67.09 & 7.61 \\
\hline ration2(FBS) Tested & & 87.64 & 9.77 & 23.85 & 1.88 & 52.14 & 12.36 & 65.58 & 6.95 \\
\hline
\end{tabular}

Feedstuffs and feces analysis: The concentrate feed mixture, fresh fodder beet, fodder beet silage, rice straw and feces samples were analyzed according to A.O.A.C. (1995) methods.

Biochemical analysis of blood serum: Total protein was determined as described by Armstrong and Carr (1964). Albumin was determined as described by Doumas et al. (1971). Globulin was calculated by subtraction, while $\mathrm{A} / \mathrm{G}$ ratio was calculated by dividing. Urea was determined by the method of Curtius and Marce (1972). Glucose was determined calorimetrically according to the method of Siest et al. (1981). Serum glutamic-pyruvic transaminase (GPT) and glutamic-oxaloacetic transaminase (GOT) were determined calorimetrically according to the method of Reitman and Frankel (1957).

Milk analysis: Milk was analyzed for fat, total solids, total protein and ash according to Ling (1963), while solids not fat (SNF) content was calculated by difference. Lactose was determined according to the method of Barnett and Abd El-Tawab (1957). Fat -corrected milk (FCM) 4\% fat was calculated by using the following equation according to Gaines (1928). $\quad F C M=0.4$ (Milk yield) +15 (Fat yield)

Feed conversion (FC): Feed coversion is expressed as amount of unit feed (kilograms or grams) from DM , CP and TDN to produce one kilogram FCM .

Economical efficiency: Values were calculated as a ratio between price of FCM yield and the cost of feed consumed. The prices were based on Egyptian market in 2016-2017.

Statistical analysis: The data were analyzed by one way analysis of variance (repeated measurements) using SAS program (SAS, 1998). The least of significances was applied to test the differences among the different treatment means according to Duncan (1955). The following model was used to describe the data of milk and blood parameters.

$$
\mathrm{Y}_{\mathrm{ijk}}=\mathrm{u}+\mathrm{R}_{\mathrm{i}}+\mathrm{e}_{\mathrm{ik}}+\mathrm{P}_{\mathrm{j}}+(\mathrm{RP})_{\mathrm{ij}}+\mathrm{e}_{\mathrm{ijk}}
$$

Where: $Y_{i j k}$ is observation, $\mu$ is overall mean, $R_{i}=$ is the effect due to tested ration $i, P_{j}=$ is the effect due to period $\mathrm{j},(\mathrm{RP})_{\mathrm{ij}}$ is interaction between $\mathrm{R}$ and $\mathrm{P}, \mathrm{e}_{\mathrm{ijk}}$ is experimental error

While the data of digestibility trials used the following model

$$
Y i j=u+R_{i}+e_{i j} \quad .
$$




\section{RESULTS AND DISCUSSION}

Nutrients digestibility: Data of Table (3) indicated that animals received fresh fodder beet ration (FB) recorded the highest values of DM ,OM , CP , EE and NFE digestibility followed by fodder beet silage ration (FBS) group. Fodder beet animals had significant $(\mathrm{P}<0.05)$ increase in OMD, CPD and NFED, while FBS group had the highest value in CFD $(\mathrm{P}<0.05)$. Consequently, FB ration had the highest TDN value $(67.09 \%)$ followed by FBS ration $(65.58 \%)$ then the control ration $(62.16 \%)$. Gabra et al. (1992) in metabolism trials with sheep and feeding trial with cows revealed that the replacing of concentrates by fodder beet silage significantly increased all nutrients digestibility. Also, Mahmoud et al. (1992) reported that the feeding of fodder beet roots silage for lactating cows increased all nutrients digestibility. Fodder beet exhibited more efficiency for increasing nutrients digestibility. This might be due to that fodder beet ration (FB) had the highest values of NFE and the lowest CF value. During ensiling fodder beet silage contained an amount of poor quality roughages such as bean straw or rice straw to be mixed with the ensiled roots to reduce its humidity. That might affect nutrients digestibility of silage to be lower than FB. On the contrary, FBS had higher CF \% . Several investigators showed an improvement in CF digestibility due to ensiling due to its positive effect on hemicellulose digestibility (Gabra et al., 1992 and Dewar et al., 1989) .

Table (3). Effect of tested rations on nutrients digestibility \% of lactating buffaloes.

\begin{tabular}{lcccc}
\hline Item & \multicolumn{4}{c}{ Treatment } \\
\cline { 2 - 5 } Digestibility \% & Control (C) & T1 (FB) & T2 (FBS) & \pm SE \\
\hline DM & 60.23 & 64.14 & 61.30 & 1.287 \\
OM & $68.12^{\mathrm{b}}$ & $73.32^{\mathrm{a}}$ & $70.50^{\mathrm{ab}}$ & 1.03 \\
CP & $68.86^{\mathrm{b}}$ & $76.20^{\mathrm{a}}$ & $71.14^{\mathrm{b}}$ & 1.063 \\
CF & $54.60^{\mathrm{b}}$ & $57.80^{\mathrm{ab}}$ & $59.90^{\mathrm{a}}$ & 1.012 \\
EE & 76.80 & 79.21 & 78.73 & 1.26 \\
NFE & 76.66 & 80.46 & 78.67 & 1.429 \\
\hline
\end{tabular}

$a, b$ Means per each row per each item are different $(P<0.05)$. Control treatment $\{C\}$ animals fed ration consisted of $60 \%$ concentrate feed mixture (CFM) and $40 \%$ rice straw (RS) in DM basis. Tl (FB) animals fed ration consisted of $40 \%(C F M)+20 \%$ fresh fodder beet root and $40 \%(R S)$ in DM basis .T 2 (FBS) animals fed ration consisted of 40 $\%(C F M)+20 \%$ fodder beet root silage and $40 \%(R S)$ in DM basis.

It may be of interest to note that the incorporation of fodder beet roots in the tested rations serves three purposes: (a) reduced the fiber content compared with control, (b) improved digestion coefficients and nutritive value, and (c) provided more readily available energy which improves protein utilization (Mahmoud et al ., 1992 and Bendary et al .,1993). The increase in dietary fermentable carbohydrates in FB may further reduce the amount of $\mathrm{NH}_{3}$ absorbed across the rumen wall, because of the potential for increased $\mathrm{N}$ capture in microbial protein. Thus, it is reasonable to expect a reduced need for hepaticureagenesis for $\mathrm{NH}_{3}$ disposal (Lapierre and Lobley (2001).

Also, Salewski (1991) reported that fodder beet is highly digestible and energy-rich forage. Its nutritive and physiological effects are similar in part to those of concentrates. In ruminant rations, especially hay or grass silage-based diets, sugars slowly released by rumen fermentation activate microorganisms that degrade organic matter in preserved grass. Digestibility of the total diet is thereby increased, increasing transit time and stimulating feed intake. This would result in maintaining the desirable balance between ruminally degraded proteins and fermentable carbohydrates in the diet and, thus, improving nitrogen utilization in animal husbandry (Eriksson et al., 2004). 
Gibbs (2011) reported that ME values obtained from in-vivo testing of fodder beet are around 12.012.5 $\mathrm{MJ} \mathrm{kg}^{-1}$, compared with 10.5-11.5 $\mathrm{MJ} \mathrm{kg}^{-1}$ for kale fed as a whole crop. The perceived protein deficiency in fodder beet may not be as severe as is commonly assumed. Replacement of fodder beet roots up to 50\% from CFM in dairy goats and ewes did not significantly affect, OM, E.E and NFE digestibility (Mousa , 2011).). recently, fodder beet recommended as a source of biomethane due to its high fresh matter yield and digestibility (Laufer et al., 2016). Also, Jonker, (2017) showed that diets with fodder beet decreased methane emissions from dry and lactating dairy cows by $18 \%$ less $\mathrm{CH} 4$ (g/day) and had $28 \%$ lower $\mathrm{CH} 4$ yield $(\mathrm{g} / \mathrm{kg}$ DM intake; $\mathrm{P}<0.001)$ than did cows grazing kale+Str.

Biochemical constituents of blood: Data of Table (4) showed that FB treated group had highest values of serum TP, Albumin and A/G ratio, then FBS group had higher values of serum TP, albumin and A /G ratio than those of control, however, a significantly $(\mathrm{P}<0.05)$ higher values were detected for only the serum albumin and $\mathrm{A} / \mathrm{G}$ ratio. These results might be due to the higher digestible protein and high energy intake for fodder beet and fodder beet silage treated animals than control group consequently, due to the higher microbial protein synthesis which increased ruminal TPN concentration, which led to more absorbed amino acids. Alert et al. (1994) investigated protein and amino acids flow in the digestive tract from various carbohydrate sources using 2 bulls (from 285-398 and 285-408 kg), fitted with duodenal reentrant cannulae, and they were given 10 diets containing $60 \%$ concentrates. they concluded that amino acid synthesis was highest when cattle were given fodder beet or sugar beet pulp and lowest in dried sugar beet pulp. Fodder beet can increase the rapidly fermentable energy to the microbes to convert excess protein $(\mathrm{N})$ in the rumen (utilized by cow creating more protein in milk) so that less excess protein (N) is excreted in the cow's urine (DBC, 2015). Recent study by Pacheco et al. (2016) on plasma amino acids in cows fed fodder beet, they reported that total AA concentrations were 1859, 1867 and 2024 $\mathrm{Mmol} / \mathrm{L}$ for RG, low FB and high FB, respectively and non significant changes in the $\mathrm{N}$ economy of the lactating dairy cows. The causes of the changes in circulating AA observed in this short-term experiment and their long-term consequences need to be understood if FB is to be recommended as an alternative feed for dairy herds to help mitigate losses of $\mathrm{N}$ to the environment.

Table (4). Overall mean of blood serum constituents in tested lactating buffaloes.

\begin{tabular}{lcccc}
\hline Item & \multicolumn{3}{c}{ Treatment } \\
\cline { 2 - 5 } & Control $(\mathrm{C})$ & T1 $(\mathrm{FB})$ & T2 $\{\mathrm{FBS}\}$ & + SE \\
\hline Total protein $(\mathrm{gm} / 100 \mathrm{ml})$ & 6.55 & 6.73 & 6.66 & 0.07 \\
Albumin $(\mathrm{gm} / 100 \mathrm{ml})$ & $3.61^{\mathrm{b}}$ & $3.88^{\mathrm{a}}$ & $3.75^{\mathrm{ab}}$ & 0.06 \\
Globulin(gm / 100 ml) & 2.94 & 2.85 & 2.90 & 0.06 \\
A / G ratio & $1.23^{\mathrm{b}}$ & $1.36^{\mathrm{a}}$ & $1.29^{\mathrm{ab}}$ & 0.03 \\
urea content $(\mathrm{mg} / 100 \mathrm{ml})$ & $45.40^{\mathrm{b}}$ & $49.1^{\mathrm{a}}$ & $48.90^{\mathrm{a}}$ & 0.71 \\
Glucose(mg / 100 ml) & $63.50^{\mathrm{b}}$ & $69.66^{\mathrm{a}}$ & $66.48^{\mathrm{b}}$ & 0.89 \\
GPT(units/ 100ml). & 32.50 & 31.10 & 32.80 & 0.82 \\
GOT(units/ 100 ml). & 129.30 & 128.5 & 131.57 & 1.28 \\
\hline
\end{tabular}

$a, b$ Means per each row per each item are different $(P<0.05)$.

Regarding the effect of feeding fodder beet on serum glucose, FB treatment achieved the highest $(\mathrm{P}<0.05)$ value, followed by FBS treatment then the control group. This increase in serum glucose might be due to the higher NFE content, low fiber content and to the parallel increase in nutrients digestibility and TDN of the rations containing FB or FBS. This may be led to an increase in propionic acid production and thus increased glucose synthesis. Feeding fodder beet increased ME intake and tended to decrease the ratio lipogenic / glucogenic VFA, by increased propionate and butyrate at the expense of acetate (Eriksson, 2003). Also, data indicated that FB and FBS treated animals had significantly higher values of urea than control group $(45.5 \mathrm{mg} / 100 \mathrm{ml})$ and they both had about similar values (49.1 and $48.9 \mathrm{mg} / 100 \mathrm{ml}$., resp.). In the present study, the treatment with fodder beet either fresh or silage did not affect the transaminase enzymes concentration in lactating buffalo.

Milk yield: The present results in Table (5) indicated that FB animals recorded the highest significant values of milk yield in all lactation periods $(6.99 \mathrm{~kg} / \mathrm{d})$ followed by FBS animals $(6.69 \mathrm{~kg} / \mathrm{d})$, whereas the control animals showed the least mean value $(6.51 \mathrm{~kg} / \mathrm{d}$.). These findings are in accordance with those 
of several investigators working on dairy cattle, Castle et al. , (1963) found that inclusion of fresh fodder beet in ration provides more readily available energy which improve milk yield, Aaes (1993) concluded that, with rations with high amounts of easily digestible feedstuffs, the feeding method had a great positive effect on feed intake and milk production when given as total mixed rations. Moreover, Fisher et al. (1994) and Phipps et al. (1995) fed fodder beet to dairy cows and found an increase in milk yield. Also, on fodder beet silage, Gabra et al. (1992) revealed that the replacing of concentrates by fodder beet silage $(40 \%)$ in lactating cows ration increased milk yield by $6.7 \%$ and fat yield by about $20 \%$. Also, Bendary et al. , (1993) and Bendary and Omar (1997) found that inclusion fodder beet roots silage in ration for lactating cows improved milk yield. Fisher et al. (2006) showed that feeding fodder beet for lactating cows increased milk yield, composition and yield of constituents, but the effect was significant for milk protein content only ( $\mathrm{P}<0 \cdot 01)$. Replacement of fodder beet roots up to $50 \%$ from CFM in dairy goats and ewes diets improved milk yield, than the control by about 12.09 and $24.38 \%$, respectively (Mousa , 2011).

Table (5). Effect of tested rations on buffaloes milk yield during the first periods of lactation.

\begin{tabular}{lcccrc}
\hline \multirow{2}{*}{ Week } & \multicolumn{5}{c}{ Treatment } \\
\cline { 2 - 6 } Control $\{\mathrm{C}\}$ & $\mathrm{T} 1\{\mathrm{FB}\}$ & $\mathrm{T} 2\{\mathrm{FBS}\}$ & Overall m. & \pm SE \\
\hline WW & 6.12 & 6.27 & 5.94 & 6.11 & .132 \\
6W & 6.56 & 6.81 & 6.70 & 6.69 & .132 \\
8W & $7.02(100 \%)$ & $7.47(100 \%)$ & $7.17(100 \%)$ & 7.22 & .132 \\
10W & $6.75(96.2)$ & $7.28(97.5 \%)$ & $6.98(97.4 \%)$ & 7.01 & .132 \\
12W & $6.51(92.7 \%)$ & $7.11(95.2 \%)$ & $6.76(94.3 \%)$ & 6.79 & .132 \\
\hline Overall treat. $\mathrm{m}$. & $6.14(87.5 \%)$ & $6.99(93.6 \%)$ & $6.59(92.0 \%)$ & 6.57 & .132 \\
\pm SE & $6.51^{\mathrm{b}}$ & $6.99^{\mathrm{a}}$ & $6.69^{\mathrm{ab}}$ & 6.73 & \\
\hline
\end{tabular}

$a, b$ Means per each row per each item are different $(P<0.05)$.

It is of interest to note that the present results are in parallel with the results previously obtained with digestibility trial (Table, 3) which showed that all nutrients were digested more by FB group followed by FBS group than that of control. Consequently, FB had the highest TDN and DP values, while FBS had higher TDN value than control ration, also, the relative improvement in milk production by feeding FB or FBS might be due to the higher serum glucose values recorded by treated animals. Zitnan (1993) concluded that the replacement of barley with fodder beet in cattle diet increased rumen TVFA and propionate concentration .

It should be noted that after the average daily milk yield reached the maximum at the first 6 weeks of lactation, the FB treated animals had the least decreased rate of daily milk yield through the 8, 10 and 12 weeks of lactation $(97.5,95.2$ and $93.6 \%$, resp.) from the maximum daily milk yield at 6 weeks of lactation, followed by FBS treated group $(97.4,94.3$ and $91.9 \%$, resp.) while, the control group had the highest decrease rate $(96.2$, 92.7 and $87.5 \%$, resp.).

$4 \%$ Fat-corrected milk (FCM) yield: Data of Table (6) indicated that treated animals had significantly $(\mathrm{P}<0.05)$ higher FCM yield values $(10.02$ and $9.65 \mathrm{~kg} / \mathrm{d})$ than that of control animals $(8.90 \mathrm{~kg} / \mathrm{d})$. Within treated animals, FB animals had significantly $(\mathrm{P}<0.05)$ higher FCM yield value than that of FBS group.

Data also revealed that FB group had higher fat-corrected milk yield value by about $12.59 \%$ than control group, while FBS group had higher FCM yield value by about $8.43 \%$ than control group. These results might be attributed to that FCM yield depends mainly on milk yield and milk fat \% FB group had highest values of milk yield followed by FBS group, then, control group. while FBS group recorded the highest value of milk fat $\%$. Many workers have reported that feeding fodder beet had improvement in milk production, Roberts, (1987); Darwish et al. (1989) and Mcllmoyle et al. (2002) found that inclusion of fodder beet roots in Friesian dairy cows ration (25\% of DM) positively affected milk yield and components. On lactating goats Mohammed (2002) reported that goats fed fodder beet roots silage had the highest significantly FCM yield values than the control and other treatments. Similar results of milk yield were also reported by Abdu [2001], who found that the overall milk yield mean of weeks significantly $(\mathrm{P}<0.01)$ increased gradually with time progress to reach its maximum at the $6^{\text {th }}$ week, then decreased $(\mathrm{P}<0.01)$ gradually until the $12^{\text {th }}$ week. while Khattab et al. $(2000)$ found that buffaloes milk yield recorded the highest level in the $7^{\text {th }}$ week and reduced gradually with week advancement. It is of interest to note that after the average FCM yield values reached the maximum at the 6 
weeks of the first lactation, the FB treated animals had the least decreased rate of FCM yield through the 8,10 and 12 weeks of lactation $(99.2,97.5$ and $96.9 \%$, resp.)from the maximum FCM yield values at 6 weeks of lactation ,followed by FBS treated group ( $99 ., 96.5$ and $95.1 \%$ ), while the control group had the highest decrease rate $(97.4,95.2$ and $91.2 \%$ respectively).

Table (6). Effect of tested rations on $4 \%$ fat-corrected milk (FCM)yield during lactation periods.

\begin{tabular}{lccccc}
\hline \multirow{5}{*}{ Week } & \multicolumn{5}{c}{ Treatment } \\
\cline { 2 - 6 } Control $\{\mathrm{C}\}$ & $\mathrm{T} 1\{\mathrm{FB}\}$ & $\mathrm{T} 2\{\mathrm{FBS}\}$ & Overall wk m. & $\pm \mathrm{SE}$ \\
\hline $\mathrm{WW}$ & 8.48 & 9.03 & 8.6 & 8.70 & 0.170 \\
$6 \mathrm{~W}$ & 8.93 & 9.72 & 9.61 & 9.42 & 0.170 \\
$8 \mathrm{~W}$ & $9.37(100 \%)$ & $10.52(100 \%)$ & $10.16(100 \%)$ & 10.02 & 0.170 \\
$10 \mathrm{~W}$ & $9.13(97.4 \%)$ & $10.5(99.7 \%)$ & $10.07(99.1 \%)$ & 9.85 & 0.170 \\
$12 \mathrm{~W}$ & $8.92(95.2 \%)$ & $10.26(97.5 \%)$ & $9.8(96.5 \%)$ & 9.64 & 0.170 \\
\hline Overall treat. $\mathrm{m}$. & $8.55(91.2 \%)$ & $10.2(96.9 \%)$ & $9.66(95.1 \%)$ & 9.47 & 0.170 \\
\hline \multicolumn{7}{c}{ SE } & $8.90^{\mathrm{c}}$ & $10.02^{\mathrm{a}}$ & $9.65^{\mathrm{b}}$ & 9.52 & \\
\hline a,b,c Means per each row per each item are different $(P<0.05)$. & $12.59 \%$ & $8.43 \%$ & & \\
\hline
\end{tabular}

\section{Milk constituents:}

Milk fat: The presented data (Table, 7) showed that FBS group had the highest mean values of fat content in all experimental periods and showed highly significant increase in milk fat overall mean (6.95\%), followed by FB treated animals. which recorded higher fat content in all experimental periods and significant increase in milk fat overall mean $(6.89 \%)$ than the control animals $(6.44 \%)$.

Table (7). Effect of tested rations on buffalo's milk fat \% during the periods of lactation .

\begin{tabular}{lccccc}
\hline & \multicolumn{5}{c}{ Treatment } \\
\cline { 2 - 6 } Week & Control $\{\mathrm{C}\}$ & $\mathrm{T} 1\{\mathrm{FB}\}$ & $\mathrm{T} 2\{\mathrm{SFB}\}$ & W. Ov.11 m. & \pm SE \\
\hline 2W & 6.57 & 6.93 & 6.98 & 6.83 & 0.079 \\
4W & 6.41 & 6.85 & 6.90 & 6.72 & 0.079 \\
6W & 6.23 & 6.72 & 6.79 & 6.58 & 0.079 \\
8W & 6.35 & 6.83 & 6.92 & 6.7 & 0.079 \\
10W & 6.47 & 6.95 & 7.00 & 6.81 & 0.079 \\
12W & 6.62 & 7.06 & 7.11 & 6.93 & 0.079 \\
\hline Treat. Ovall m. & $6.44^{\mathrm{b}}$ & $6.89^{\mathrm{a}}$ & $6.95^{\mathrm{a}}$ & 6.76 & \\
\hline \pm SE & .056 & .056 & .056 & & \\
\hline
\end{tabular}

$a, b$ Means per each row per each item are different $(P<0.05)$.

The main source of energy in fodder beet is simple sugars such as sucrose, and beet has a low crude fiber content, it is not possible to identify the sucrose content of the beet as the main reason for improved milk fat content. There may therefore be a complex interaction between the supply of sugar from beet and the fiber in the diet which need further investigation (Roberts, 1987).

These results could be attributed to increase the amounts of digestible crude fiber in tested rations special in FBS ration that lead to increase acetic acid production, consequently increase milk fat content .

These results support Roberts (1987) findings who reported that feeding fodder beet to calving cows and heifers had a significant improvement in the fat content of the milk and yield of constituents. Similar situation 
was found by Darwish et al. (1989) and Phipps et al. (1995) when they fed Friesian dairy cows on fodder beet roots.

Data in Table (8) revealed that fresh fodder beet recorded the highest values $(\mathrm{P}<0.05)$ of milk total solids content, milk SNF content, milk TP and lactose content, while fodder beet silage treated animals had significant increase in total solids content and non significant increase in milk SNF content, milk TP and ash content compared to control group. Within treated groups, FB treatment recorded higher $(\mathrm{P}<0.05)$ TS value $(16.91 \%)$ than that of FBS treated group $(16.75 \%)$.

These results agree with those of Roberts (1987), Darwish et al. (1989) and Phipps et al. (1995). They found that feeding fodder beet increased milk total solids content and yield for Friesian dairy cows. This finding might be attributed to that milk TS content depends mainly on milk fat and milk SNF content and fodder beet treated group had highest values of milk SNF\% followed by FBS treated group, then control group, while the increases in SNF \% with FB treatment due to the increase in milk TP, ash and lactose content comparing with control group.

Table (8). Overall mean values of milk yield and milk composition of lactating buffaloes fed experimental rations.

\begin{tabular}{lllll}
\hline Item & \multicolumn{3}{c}{ Treatment } \\
\cline { 2 - 5 } & Control@ & T1 $\{\mathrm{FB}\}$ & T2 $\{\mathrm{FBS}\}$ & \pm SE \\
\hline Milk yield (kg) & $6.51^{\mathrm{b}}$ & $6.99^{\mathrm{a}}$ & $6.69^{\mathrm{ab}}$ & 0.094 \\
F C M yield (kg) & $8.90^{\mathrm{c}}$ & $10.02^{\mathrm{a}}$ & $9.65^{\mathrm{b}}$ & .1204 \\
Total solids\% & $16.13^{\mathrm{c}}$ & $16.91^{\mathrm{a}}$ & $16.75^{\mathrm{b}}$ & 0.06 \\
Fat \% & $6.44^{\mathrm{b}}$ & $6.89^{\mathrm{a}}$ & $6.95^{\mathrm{a}}$ & 0.056 \\
SNF \% & $9.69^{\mathrm{b}}$ & $10.02^{\mathrm{a}}$ & $9.80^{\mathrm{ab}}$ & 0.071 \\
Total protein\% & $4.03^{\mathrm{b}}$ & $4.27^{\mathrm{a}}$ & $4.11^{\mathrm{ab}}$ & 0.025 \\
Lactose\% & $4.77^{\mathrm{b}}$ & $4.86^{\mathrm{a}}$ & $4.74^{\mathrm{b}}$ & 0.046 \\
Ash \% & 0.786 & 0.800 & 0.811 & 0.009 \\
\hline
\end{tabular}

$a, b, c$ Means per each row per each item are different $(P<0.05)$.

These increases in milk TP with FB treatment might be due to the increases in digestible protein amount available for animals fed fodder beet ration. The mechanisms of this effect may indeed lie in a rumen microbial response to the feeding of fodder beet by improving protein synthesis and the quantity of microbial protein and un-degraded dietary protein passing into the small intestine (Fisher et al., 1994). Fodder beet can increase the rapidly fermentable energy to the microbes to convert excess protein $(\mathrm{N})$ in the rumen (utilized by cow creating more protein in milk) so that less excess protein $(\mathrm{N})$ is excreted in the cow's urine (DBC, 2015).

Milk constituents yield: Data in Table (9) showed that FB treated animals recorded the highest values $(\mathrm{P}<0.05)$ of all milk constituents yield followed by FBS treated group, then , control group. Fisher (2006), feeding fodder beet for lactating cows increase milk yield, composition and yield of constituents, but the effect was statistically significant for milk protein content only ( $\mathrm{P}<0 \cdot 01)$. Also, Mousa, (2011).) found that the replacement of fodder beet roots up to 50\% from CFM in dairy goats and ewes diets improved milk constituents yield than the control.

Table (9). Overall mean of milk constituents yield in tested lactating buffaloes fed treatments .

\begin{tabular}{lllll}
\hline Item & \multicolumn{3}{c}{ Treatment } \\
\cline { 2 - 5 } & Control $\{\mathrm{C}\}$ & T1 $\{\mathrm{FB}\}$ & T2 $\{\mathrm{FBS}\}$ & \pm SE \\
\hline Total solids $(\mathrm{gm} \mathrm{h} / \mathrm{d})$ & $1052^{\mathrm{b}}$ & $1182^{\mathrm{a}}$ & $1121^{\mathrm{ab}}$ & 15.21 \\
Fat $(\mathrm{gm} \mathrm{h} / \mathrm{d})$ & $419.2^{\mathrm{c}}$ & $481.6^{\mathrm{a}}$ & $465.0^{\mathrm{a}}$ & 5.49 \\
milk SNF $(\mathrm{gm} \mathrm{h} / \mathrm{d})$ & $630.82^{\mathrm{b}}$ & $700.4^{\mathrm{a}}$ & $655.6^{\mathrm{b}}$ & 10.8 \\
Total protein $(\mathrm{gm} \mathrm{h} / \mathrm{d})$ & $262.3^{\mathrm{b}}$ & $298.5^{\mathrm{a}}$ & $275.0^{\mathrm{b}}$ & 3.48 \\
Lactose $(\mathrm{gm} \mathrm{h} / \mathrm{d})$ & $310.5^{\mathrm{b}}$ & $339.7^{\mathrm{a}}$ & $317.1^{\mathrm{b}}$ & 6.43 \\
Ash $(\mathrm{gm} \mathrm{h} / \mathrm{d})$ & $51.2^{\mathrm{b}}$ & $55.9^{\mathrm{a}}$ & $54.3^{\mathrm{a}}$ & 0.847 \\
\hline
\end{tabular}

$a, b, c$ Means per each row per each item are different $(P<0.05$ 
Feed conversion and economical efficiency: Feed conversion (FC) is expressed as amount of units fed (kilograms or grams) from DM, CP and TDN to produce one kilogram FCM (Table 10). Data clearly indicated that FB treated group showed more efficient values of DM , CP and TDN (1240, 123.7 and 833 $\mathrm{gm} / \mathrm{kg}$ FCM, respectively), while control group consumed the respective values (1390, 138.1 and $869 \mathrm{gm}$ / $\mathrm{kg}$ FCM ). An intermediate values were those of fodder beet silage treated animals which had more improvement in DM , CP and TDN efficient values (1290, 126.7and $851 \mathrm{gm} / \mathrm{kg}$ FCM, respectively) than control group.

It could be concluded that replacing $33.3 \%$ of concentrate feed mixture with FB in the ration of lactating buffaloes improved DM conversion by $12 \%, \mathrm{CP}$ conversion by $11.7 \%$ and TDN conversion by $4.3 \%$ compared to control group. Whereas feeding FB had intermediate improvement values. These improvement are be attributed to their effect on FCM yield although they consumed approximately the same quantity of DM and quantity of CP (1245 and $1252 \mathrm{gm} / \mathrm{h} / \mathrm{d})$ for buffaloes group fed FB and FBS, respectively compared to control group $(1241 \mathrm{gm} / \mathrm{h} / \mathrm{d})$. Also, due to their positive effects on the digestibility and metabolism of lactating buffaloes which led to an improvement in efficiency of feed utilization. The results clearly indicate that fresh fodder beet treated group had the lowest feed cost to produce one kg FCM (2.88 L.E.) followed by FBS treatment which recorded (2.9 L.E.), while the control group had the highest value (3.51 L.E.).

Table (10). Economic efficiency of lactating buffalos treated by tested ration.

\begin{tabular}{|c|c|c|c|}
\hline \multirow[t]{2}{*}{ Item } & \multicolumn{3}{|c|}{ Treatment } \\
\hline & Control $\{\mathrm{C}\}$ & $\mathrm{T} 1\{\mathrm{FB}\}$ & $\mathrm{T} 2\{\mathrm{SFB}\}$ \\
\hline DMI ( kg / h/ d ) & 12.41 & 12.45 & 12.52 \\
\hline $\mathrm{CPI}(\mathrm{kg} / \mathrm{h} / \mathrm{d})$ & 1.229 & 1.24 & 1.223 \\
\hline TDNI $(\mathrm{kg} / \mathrm{h} / \mathrm{d})$ & 7.712 & 8.35 & 8.21 \\
\hline Feed efficiency (DM kg/ kg FCM) & 1.39 & 1.24 & 1.29 \\
\hline CPI gm / kg FCM yield. & 138.1 & 123.7 & 126.7 \\
\hline TDNI gm / kg FCM yield. & 0.867 & 0.833 & 0.851 \\
\hline Cost of feed consumed (L.E/d) * & 31.25 & 28.9 & 28.0 \\
\hline $4 \%$ FCM yield $(\mathrm{kg} / \mathrm{d})$ & $8.90^{\mathrm{c}}$ & $10.02^{\mathrm{a}}$ & $9.65^{\mathrm{b}}$ \\
\hline Price of $4 \%$ FCM yield (L.E /d) * & 662.3 & 70.14 & 67.55 \\
\hline Cost of feed cons. / $\mathrm{kg} 4 \%$ FCM (L.E) * & 3.51 & 2.88 & 2.90 \\
\hline Economic efficiency & 1.99 & 2.43 & 2.41 \\
\hline
\end{tabular}

$a, b, c$ Means per each row per each item are different $(P<0.05$

Regarding to the effect of experimental treatments on economical efficiency, data of Table (10) clearly indicated that fodder beet treated group had the highest economical efficiency value (2.43) followed by FBS treatment (2.41) then the control group which had the lowest value (1.99).

It is of interest to note that fodder beet ration was more economically efficient than control ration by $22.1 \%$, also fodder beet silage ration proved to be economically efficient than control ration by 21.1 $\%$.These results could be attributed to the positive correlation between daily FCM yield and economic efficiency, and also to the positive correlation between the feed efficiency and the economic efficiency.

The beneficial effect of including fodder beet on feed conversion (FC) and economic efficiency agree well with those found by Roberts, (1987), Darwish et al . (1989), Fisher et al . (1994), Phipps (1995) and Mcllmoyle et al.(2002 ) with fodder beet on lactating cattle. and, Mahmoud et al ., (1992), Bendary et al. (1993) and Bendary and Omar (1997) with silage of fodder beet on lactating cattle and Mohammed (2002) on lactating goat .

Two feeding trials on lactating cows were carried out by Khogali et al (2011) to investigated The feeding value of FB was compared to fodder sorghum Abu70 (Sorghum bicolor L. moench), they concluded that DM intake of cows $(\mathrm{kg} / \mathrm{h} / \mathrm{d})$ fed on FB $(2.88 \mathrm{~kg})$ was less than that fed on fodder Abu 70 
$(6.45 \mathrm{~kg})$. Results have clearly demonstrated the efficiency of feeding FB to dairy cattle compared to traditional Abu 70, due to more profitable milk production and cheaper cost of feeding without having any negative effect on either milk yield or composition. Feeding costs decreased significantly along the two seasons by $>30 \%$ when cows fed on FB. Also, Mousa (2011) reported that the replacement of fodder beet roots up to $50 \%$ from CFM in dairy goats and ewes diets improved productive performance and economical efficiency and decreased feed cost than the control group.

\section{REFERENCES}

Aaes, O. (1993). Total mixed rations vs. separate feeding of concentrate rich rations given restrictively or ad lib. to dairy cows. Forskningsrapport- fra- Statens- Husdyrbrugsforsog. 1993, No. 16, 23 pp.; 29 ref.

Abd El-Sattar M. and A.A. Nour (1997). Feed evaluation of some Egyptian winter green forages and their mixtures with reference to quality and cost of nutrients. Egyptian J. Nutrition and Feeds. :145- 159.

Abdu, M. M. (2001). Effect of some medicinal plants in the rations on productive performance of lactating animals. M. Sc.Thesis, Faculty of agriculture, Ain Shams Univ. Cairo, Egypt.

Abou-Deya, I.B. (1991). Productivity of some fodder beet cultivars as influenced by organic and mineral fertilizers under saline conditions of South Sinai. Annals of Agric .Sci., Moshtohor, 29 (1): 29.

Alert, H.J.; S. Poppe and R. Al-Munajed (1994). Studies on food conversion in the digestive tract of juvenile bulls. 1. Conversion of protein and amino acids. Archives-of- Animal-Nutrition. 47: 1, 23-35

A.O.A.C., 1995. Official Methods of Analysis. $15^{\text {th }}$ ed. Association of official analytical Chemists, Arlongton, Virginiall U S A.

Armstrong, W.D. and C.W. Carr (1964). Pysiological chemistry; Directions, $3^{\text {rd }}$ ed. p.75, Burges publishing Co. Minneapolis, Minnesota.

Barnett, A.J.G. and G. Abd El-Tawab (1957). Determination of lactose in milk and cheese. J.Sci. Food Agric.,8:437-441.

Bendary, M.M. and E.A. Omar (1997). Performance of lactating cows fed silage containing rations during summer season. J. Agric. Sci. Mansoura Univ.,22(5):1347-1355.

Bendary, M. M.; G.A. Ramadan; I.A. Abou-Selim and G.S.M. Gheit (1993). Comparing the feeding of fodder beet roots silage with traditional summer and winter rations for lactating friesian cows. J.Agric. Sci. Mansoura Univ.18(10):2844-2844.

Castle, M.E.; A.D. Drysdale and R.Waite (1963). The effect of root feeding on the intake and production of dairy cows. Journal of Dairy Research, 28, 67-74.

Curtius, H. Ch. and R. Marce (1972) Clinical Biochemisty Principles and Methods, 11, P. 1132.

Darwish, A.; M.M.E. Hassouna; A.M. Rammah and M.A.S. Abd El-Gawad (1989). Fodder beet roots in restricted rations for lactating cows. Third Egyptian-British Conference on Animal, Fish and Poultry Production, Alexandria, 7-10 October, 1989.

DBC (2015). Dairy Business. Centre (NZ). Limited. 208 Havelock Street Ashburton 7700. New Zealand. E office@dairybusiness.co.nz.

Dewar, D. L.; J.I. Andries; J.L. Boever-de and Buysse (1989). Economic feeding of dairy cows by provision of high-quality roughage. Praktische-Tierarzt. 71: 1, 35-40.

Doumas, B., W. Wabson and H. Biggs (1971). Albumin standards and measurement of serum with bromocresol green. Clin. Chem. Acta, 31:87.

Duncan, D.B. (1955). Multiple rang and Multiple F test. Biometrics, 11:1-2.

Eriksson, T. (2003). Milk production from leguminous forage, roots and potatoes: Effects on microbial protein supply and nitrogen efficiency. Doctoral diss. Dept.of Animal Nutrition and Management, SLU. Acta Universitatis agriculturae Sueciae vol. 42. 
Eriksson, T.; M. Murphy; P. Ciszuk and E. Burstedt (2004). Nitrogen balance, microbial protein production, and milk production in dairy cows fed fodder beets and potatoes, or barley. Journal-ofDairy- Science. 87 (4): 1057-1070.

Fisher, G.E.J.; M.S. Sabri and D.J. Roberts (1994). Effects of feeding fodder beet and concentrates with different protein contents on dairy cows offered silage ad libitum. Grass and Forage Science 49(1)3441.

Forbes, R.M. and W.P. Garrigus (1948). J. Animal Sci., 7: 373.

Fisher, G. E. J., M. S. Sabri and D.J. Roberts (2006). Effects of feeding fodder beet and concentrates with different protein contents on dairy cows offered silage ad libitum. Grass and Forage Science 49(1):34 - 41 .

Gabra, M.A.; M.R.M. Moustafa; A.A. Abdal-Khabir and K.E.I. Etman (1992). Partial replacement of concentrates by fodder beet silage in metabolism trials with sheep and feeding trial with cows. J. Agric. Sci., Mansoura Univ., 17(10):3140-3148.

Gaines, W. L. (1928). The energy basis of measuring energy milk in dairy cows. Univ. Illinois Agric.

Gibbs, J. (2011). Wintering cows on fodder beet. Proceedings of the South Island dairy Event Lincoln University Retrieved on 31 October 2011.

Jonker, A., D. Scobie, R. Dynes, G. Edwards, C. De Klein, Hague Helen, R. McAuliffe, A. Taylor, T. Knight and G. Waghorn (2017). Feeding diets with fodder beet decreased methane emissions from dry and lactating dairy cows in grazing systems. Animal Production Science 57, 1445-1450.

Khattab, H. M.; A. M. Kholif; H. A. El-Alamy; F.A. Salem and A. A. El-Shewy (2000). Ensiled banana wastes with molasses or whey for lactating buffaloes during early lactation. Asian-Australian J. Anim. Sci., 13(5): 619-624.

Khogali, Muna E.; Y. M. I. Dagash* and M. G. El- Hag (2011). Feeding value of fodder beet (Beta vulgaris var. Crassa) versus fodder sorghum abu sabein (Sorghum bicolor 1. Moench). Assiut Vet. Med. J.. 57(128)

Lapierre, H. and G.E. Lobley (2001). Nitrogen recycling in the ruminant: A review. Journal of Dairy Science 84(E. Suppl.): E223-236.

Laufer, D., O. Nielsen, P. Wilting, H.J. Koch and B. Märländer (2016). Yield and nitrogen use efficiency of fodder and sugar beet (Beta vulgaris L.) in contrasting environments of Northwestern Europe. Eur. J. Agron. 73:124-132.

Ling E.R. (1963). Text book of dairy chemistry. Vol.11. Practical Champan and Hall L.T.D. London $3^{\text {rd }}$ ed.pp. 140

Mahmoud, A.M.; M.M. Bendary; M.A. Harfoush and G.A Ramadan (1992). Effect of feeding fodder beet roots silage on milk yield and its costs. J. Agric. Sci. Mansoura Univ. 17(7):2296-2304

Mcllmoyle, D.G.; D.C. Patterson; D.J. Kilpatrick (2002). The effect of fodder beet inclusion on milk production and energy utilization of grass silage based diets by lactating dairy cattle. Agric. Research Institute

Mohammed, Bahira, K. (2002). Effect of feeding lactating goats rations containing sugar beet tops (dried or silage) and fodder beet roots silage on their performance. J. Agric. Sci. Mansoura Univ., 27 (11): 7301-7311.

Mousa, M.R.M. (2011). Effect of partial replacement of dietary concentrate feed mixture by fodder Beet roots on productive performance of Ewes and doe goats under the conditions of North Sinai. Asian Journal of Animal Science, 5(4): 228-242.

Moustafa, S.M.S., A.A.S. Mahgoub, M.T. Sallam, A.A. Abd El-Ghani and T.A. Deraz, (2008). Evaluation of olive pulp waste for Egyptian Buffaloes. J. Agric. Sci. Mansoura Univ., 33: 1745-1755.

Pacheco , G. Waghornb and D. Dalleyb (2016). Plasma amino acids in cows fed fodder beet. Proceedings of the New Zealand Society of Animal Production, 76: 62-64. 
Phipps, R.H.; J. D. Sutton and B.A. Jones (1995). Forage mixture for dairy cows: the effect on drymatter intake and milk production of incorporating either fermented or urea- treated whole crop wheat, brewers, grains, fodder beet or maize silage into diets based on grass silage. Centre for Dairy Research, University of Reading, Arborfield Hall Fam, Arborfield, Reading RG2 9HX.

Rammah, A. M.; F.M. Ali and M.T. Hassan (1984). Evaluation of fodder beet cultivars for different locations and years. EMCIP Puplication, 1:215.

Reitman, S. and S. Frankel (1957). Calorimetric method for the determination of serum glutamicoxaloaceticandglutamic-pyruvatetranseaminase.An. .Cin.Path.28:56.

Roberts, D. J. (1987). The effects of feeding fodder beet to dairy cows offered silage ad libitum. Grass and Forage Science 42,391-395.

Salewski, A. (1991). Fodder beet for dairy cows. Milch-Praxis., 29: 1, 63-64.

Siest, G.; J. Henny and F. Schiele (1981). Interpretation des exams de labortoire. Karger ed.206.

SAS (1998). SAS user's guide statistic. SAS ins. Inc. Cary. NC. USA.

Shehata, O. Kh. (1971). Lectures in animal production \{in Arabic\}. Animal production Department; Faculty of Agriculture Ain Shams University, Shoubra El-Kheima, Cairo, Egypt.

Van Keulen, J. and B.A.Young (1977). Evaluation of acid insoluble ash as a natural marker in ruminant in ruminant digestibility studies. J. Anim. Sci., 44: 282-287.

Zitnan, R. (1993). Level of rumen fermentation in fattening cattle during replacement of concentrates with fodder beet. Journal of Farm Animal-Science., 26: 131-134. 
تغذية الجاموس الحلاب على جذور بنجر العلف المدعم باليوريا

\author{
أحمد ممدوح منصور 1 وهلدي الزهار2

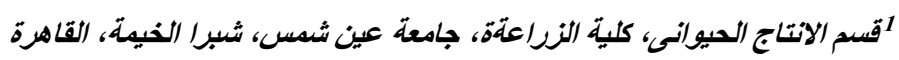

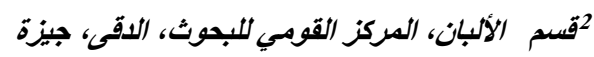

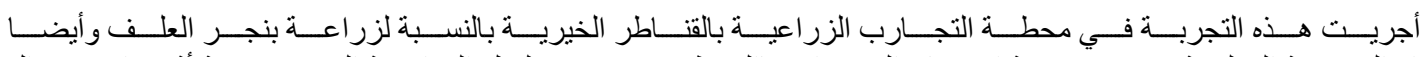

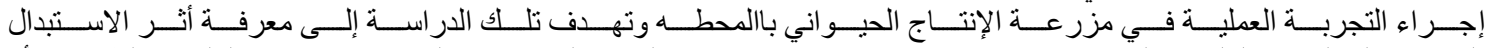

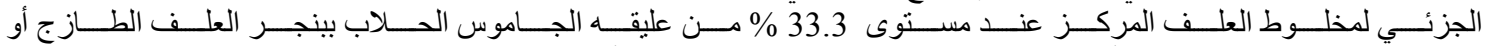

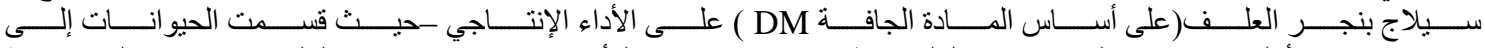

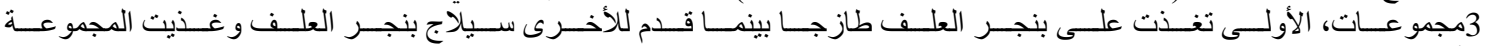
الأخيرة على عليقة المقارنة ( Control) بدون استبدال بنجر العلف.

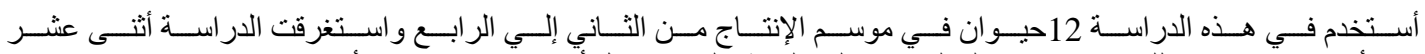

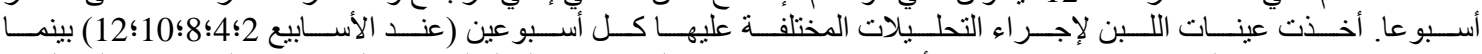

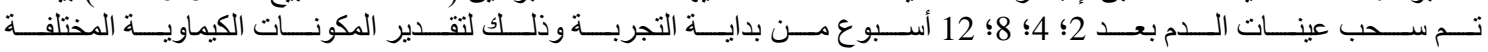
لسيرم الدم محل الدر اسة. وتم إجر اء تجربة هضم باستخدام طريقة

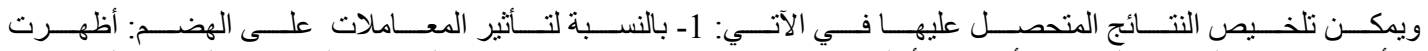

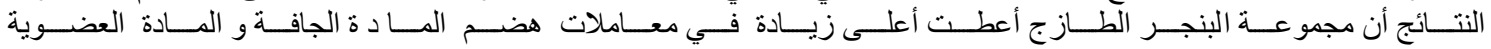

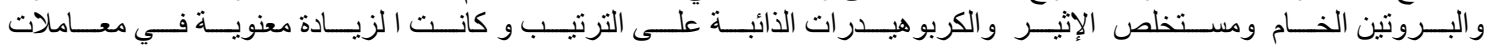

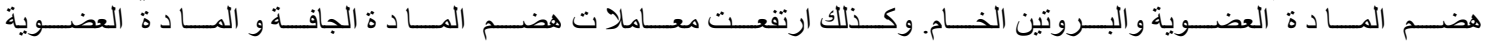

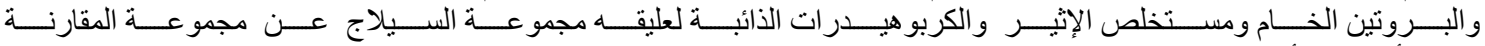

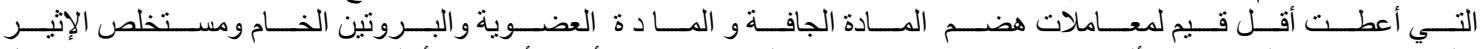

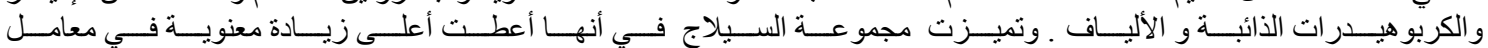

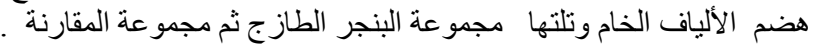

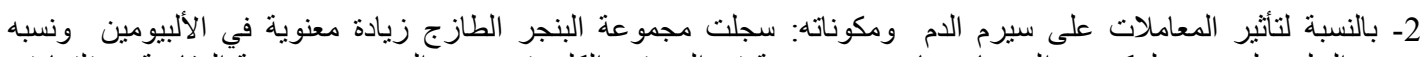

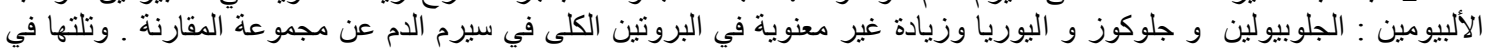

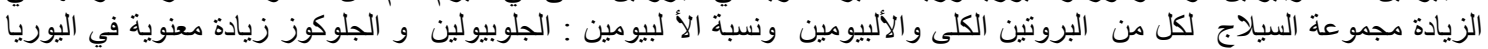

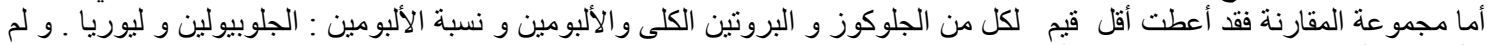

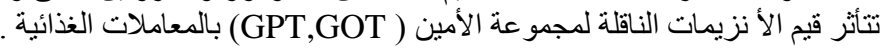

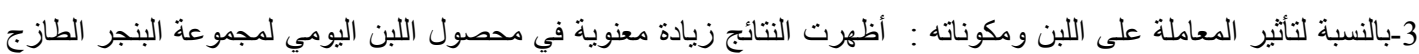

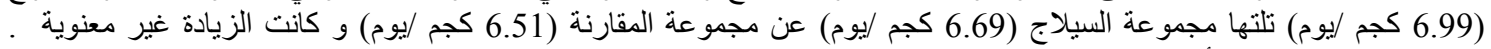

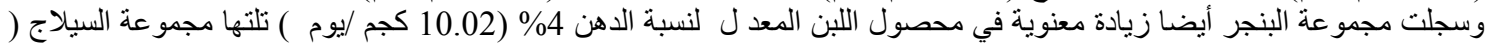

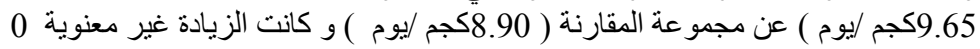

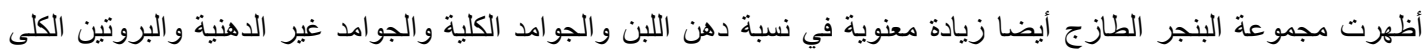

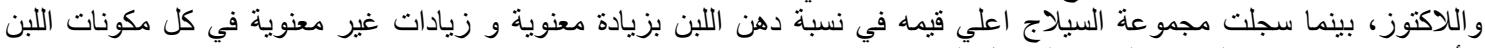
الأخري عن مجموعة المقارنة التي سجلت اقل القيم اعليم

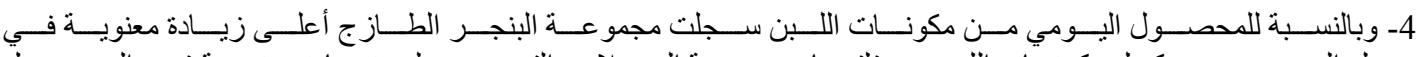

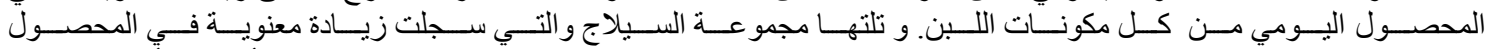

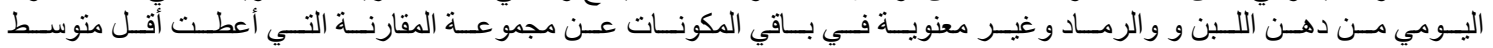
محصول يومي من مكونات اللبن.

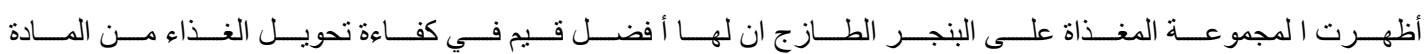

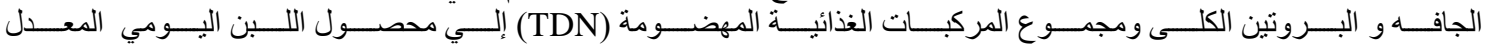
لنسبه الدهن يليها المجمو عة المغذاة على السيلاج عن مجموعة المقار الئنة

5- سجلت ا لمجمو عة المغذاة على البنجر أعلى زيادة معنوية في الكفاءة الإقتصاديه (2.43) يليها المجموعة المغنيه المغذاة على السيلاج

(2.41) عن مجموعة المقارنة التى أعطت أقل كفاءة القتصاديه (1.99). 